\title{
KARAKTERISTIK TEKS DESKRIPSI SISWA KELAS VII SMP
}

\author{
Mevi Maria Nova*, Sumadi \\ Universitas Negeri Malang
}

\begin{tabular}{|c|c|}
\hline A R T I K E L & A B S T R A K \\
\hline $\begin{array}{l}\text { Kata Kunci: } \\
\text { struktur isi } \\
\text { ciri kebahasaan } \\
\text { teks deskripsi }\end{array}$ & $\begin{array}{l}\text { Fokus penelitian ini ialah karakteristik teks deskripsi dilihat dari struktur isi dan ciri } \\
\text { kebahasaan karya siswa kelas VII SMP. Penelitian ini menggunakan racangan penelitian } \\
\text { kualitatif dan merupakan penelitian analisis teks. Hasil penelitian ini ada dua, yaitu (1) } \\
\text { struktur isi berupa identifikasi, deskripsi bagian, simpulan, tatanan unsur teks deskripsi } \\
\text { lengkap, serta tatanan unsur tidak lengkap, dan (2) ciri kebahasaan berupa kata kerja aksi, } \\
\text { kata sifat untuk mendeskripsikan objek, kata benda terkait objek yang dideskripsikan, } \\
\text { kata-kata yang dapat memancing kesan serta citra indrawi dan suasana batiniah pembaca, } \\
\text { sinonim, kata khusus, kalimat rincian, dan kalimat rincian untuk mengongkretkan. }\end{array}$ \\
\hline
\end{tabular}

\section{A R T I C L E I N F O}

\section{Keywords:}

content structure

linguistic characteristics

description text

\section{A B S T R A C T}

The focus of this research is the characteristic of the description text from the content structure and the characteristic of the language on the essay of students of class VII SMP. This study uses qualitative method and it is considered as text analysis. The results of this study are (1) the content structure is identification, section description, conclusion, the order of the full description text elements, as well as the incomplete element order and (2) the characteristics of language form action verbs, adjectives to describe objects, object related nouns described, words that can induce the impression and sensory images and the inner atmosphere of the reader, synonyms, special words, sentence details, and sentence details to grip.

\section{PENDAHULUAN}

Salah satu teks yang digunakan dalam pembelajaran tingkat sekolah menengah pertama adalah teks deskripsi. Teks deskripsi terlihat mudah dalam pengartiannya, namun pada kegiatan pembelajaran siswa seringkali salah dalam menafsirkannya. Oleh sebab itu, teks deskripsi penting untuk siswa agar siswa dapat menggambarkan suatu objek yang ia amati disekitarnya secara rinci.

Menurut Dawud (2008:9), wacana deskripsi merupakan wacana yang memerikan, menggambarkan, atau melukiskan objek dengan kata-kata. Untuk itu, sebelum menulis wacana deskripsi, siswa bertindak sebagai pengamat terhadap suatu objek. Sebagai pengamat, siswa dapat memanfaatkan pancainderanya untuk mengindera objek yang akan ditulis.

Dalam pembelajaran teks deskripsi, siswa perlu mengenali struktur isi dan ciri kebahasaan teks deskripsi. Hal tersebut perlu dilakukan siswa agar mereka dapat membuat sebuah teks deskripsi dengan baik dan benar sesuai dengan ketentuan yang sudah ditetapkan. Struktur teks deskripsi sebenarnya tidak jauh berbeda dengan teks pada umumnya. Hal yang membedakan antara teks satu dengan yang lainnya adalah aspek-aspek yang dipaparkan pada bagian pembuka, isi, dan penutup. Selain struktur, bahasa sebagai sarana berpikir secara logis merupakan hal yang mendasar. Hal ini didasarkan pada bahasa bukan hanya sebagai sarana proses berpikir melainkan penghasil konsep dan ide yang dinginkan seorang penulis.

${ }^{*}$ Corresponding author.

E-mail addresses: mevimaria8@gmail.com (Mevi Maria Nova), prof.sumadi@yahoo.com (Sumadi) 
Berdasarkan penjelasan di atas, dibutuhkan penelitian mengenai struktur dan ciri kebahasaan teks deskripsi kelas VII SMP. Penelitian ini dilaksanakan dengan tujuan agar memperoleh gambaran mengenai struktur dan ciri kebahasaan teks deskripsi.

\section{METODE}

Penelitian ini dilakukan dengan menggunakan pendekatan kualitatif. Jenis penelitian yang digunakan adalah penelitian analisis teks. Penelitian ini dilakukan di SMP Negeri 11 Malang Jl. Ikan Piranha Atas no. 185 Malang. Data dalam penelitian ini berupa struktur isi dan ciri kebahasaan teks deskripsi karya siswa kelas VII SMP Negeri 11 Malang. Sumber data dalam penelitian ini adalah teks deskripsi siswa kelas VII SMP Negeri 11 Malang.Instrumen dalam penelitian ini adalah tabel pengumpulan data. Instrumen pengumpulan data yang digunakan adalah studi dokumentasi. Langkah-langkah yang dilakukan dalam pengumpulan data meliputi (1) menyusun rancangan penelitian, (2) memilih lapangan penelitian, (3) mengurus perizinan, (4) menjajaki dan menilai lapangan, (5) memilih dan memanfaatkan informan, (6) menyiapkan perlengkapan, dan (7) persoalan etika penelitian. Analisis data yang digunakan dalam penelitian ini adalah model Miles dan Huberman. Dalam model ini ada tiga tahap yang dilakukan, yaitu (1) reduksi data, (2) penyajian data, dan (3) penarikan kesimpulan. Pengecekan keabsahan data dilakukan dengan teknik ketekunan pengamatan dan pemeriksaan sejawat. Tahap-tahap penelitian yang dilakukan adalah persiapan, pelaksanaan, dan penyelesaian.

\section{HASIL DAN PEMBAHASAN}

Struktur Isi Teks Deskripsi

Berdasarkan hasil analisis data, ditemukan struktur teks deskripsi siswa kelas VII SMP Negeri 11 Malang berupa identifikasi, deskripsi bagian, dan simpulan. Ditemukan juga tataan unsur teks deskripsi lengkap dan tataan unsur teks deskripsi tidak lengkap. Berikut paparan dan pembahasannya.

Berdasarkan hasil analisis data, ditemukan bahwa bagian identifikasi pada teks deskripsi siswa berisi gambaran umum mengenai objek yang didalamnya menjelaskan nama objek, lokasi, makna nama, dan pernyataan umum tentang objek yang akan dideskripsikan. Berikut ini dapat dilihat beberapa contoh data struktur isi bagian identifikasi.

(1)Indonesia sangat terkenal dengan pulaunya yang sangat banyak, dari yang berpenghuni sampai tidak berpenghuni. Indonesia juga memiliki pulau yang eksotis, contohnya Pulau Bali. Pulau Bali letaknya disebelah Timur Pulau Jawa, disebelah Barat kepulauan Nusa Tenggara Barat dan Pulau Bali jika dilihat secara astronomi terletak di $8,3^{\circ}$ LS $-8,5^{\circ}$ LS dan $18,25^{\circ}$ BT - $116^{\circ}$ BT. (03/SI-I)

(2)Kucingku bernama Celsie. Dia di beri nama Celsie agar dia tetap cantik. Celsie memiliki bulu yang lebat dan putih bersih. Telinganya sangat kecil dan jika dia berlari telinganya sangat tidak kelihatan karena tertutup bulu-bulu yang cantik. Matanya sangat indah, matanya berwarna coklat sangat cantik sekali untuk dipandang. Bibir mungilnya berwarna merah muda. (16/SI-I)

(3)Candi Borobudur adalah tempat wisata yang terletak di Yogyakarta dan merupakan salah satu keajaiban dunia. Candi Borobudur merupakan peninggalan yang bercorak Budhha. Candi Borobudur sangat tinggi dan besar seakan dapat menembus langit. Selain itu, disana juga terdapat Candi Prambanan. (21/SI-I)

Hasil penelitian menunjukkan bahwa pada data (03/SI-I) siswa menuliskan identifikasi yang berisi gambaran umum mengenai objek yang didalamnya menjelaskan nama objek, lokasi, dan pernyataan umum tentang objek. Pada data tersebut siswa mendeskripsikan objek berupa Indonesia yang didalamnya dijelaskan nama objek berupa Bali, lokasi berupa Pulau Bali, dan pernyataan umum berupa letak astronomis Pulau Bali. Pada data (16/SI-I) siswa menuliskan identifikasi yang berisi gambaran umum mengenai objek yang didalamnya menjelaskan nama objek, makna nama, dan pernyataan umum tentang objek. Pada data tersebut siswa mendeskripsikan objek berupa hewan peliharaan yang didalamnya dijelaskan nama objek berupa Celsie, makna nama berupa dia tetap cantik, dan pernyataan umum berupa ciri fisik Celsie. Pada data (21/SI-I) siswa menuliskan identifikasi yang berisi gambaran umum mengenai objek yang didalamnya menjelaskan nama objek, lokasi, sejarah lahirnya, dan pernyataan umum tentang objek. Pada data tersebut siswa mendeskripsikan objek berupa Candi Borobudur yang didalamnya dijelaskan nama objek berupa Candi Borobudur,lokasi berupa Yogyakarta, dan pernyataan umum berupa ciri fisik Candi Borobudur. Temuan penelitian ini sesuai dengan pendapat Harsiati (2014:20) bahwa struktur teks tanggapan deskripsi mencakup identifikasi, deskripsi bagian, dan simpulan. Identifikasi/gambaran umum berisi nama objek yang dideskripsikan, lokasi, sejarah lahirnya, makna nama, pernyataan umum tentang objek.

Berdasarkan hasil analisis data, ditemukan bahwa bagian deskripsi bagian pada teks deskripsi siswa berisi rincian mengenai objek, seperti apa yang dapat dilihat, didengar, dan dirasakan oleh penulis. Berikut ini dapat dilihat beberapa contoh data struktur isi bagian deskripsi bagian.

(4)Pantai Goa Cina memiliki pemandangan yang sangat indah, tidak kalah dengan pantai di negara-negara lain. Di Pantai Goa Cina seluruh lautnya masih bersih dan pasir putih yang sangat bersih. Apabila kita sudah berada di Pantai Goa Cina, kita bisa merasakan hembusan angin yang sejuk. Selain itu kita juga bisa mendengar suara pohon yang tertiup angin dan juga suara burung. (05/SI-DB)

(5)Ziro tidak terlalu manja. Dia suka makan dan minum susu. Dia sangat mandiri kalau sudah malam dia masuk ke kandangnya sendiri kalau dia ingin makan dia pasti mengeluarkan suara "meong" sampai berulang kali. Dia suka berkeliaran di sekitar rumahku. Dia suka bermain dengan kucing tetanggaku. (23/SI-DB) 
Hasil penelitian menunjukkan bahwa pada data (05/SI-DB) siswa menuliskan deskripsi bagian berisi rincian mengenai objek, berupa perincian yang dapat dilihat, didengar, dan dirasakan. Pada data tersebut siswa menuliskan perincian yang dapat dilihat berupa pemandangan Panta Goa Cina, perincian yang dapat didengar berupa suara pohon yang tertiup angin dan juga suara burung, dan perincian yang dapat dirasakan berupa hembusan angin yang sejuk. Pada data (23/SI-DB) siswa menuliskan deskripsi bagian berisi rincian mengenai objek, berupa perincian yang dapat dilihat, didengar, dan dirasakan. Pada data tersebut siswa menuliskan perincian yang dapat dilihat tingkah laku hewan peliharaan, perincian yang dapat didengar berupa mengeluarkan suara sampai berulang kali, dan perincian yang dapat dirasakan berupa sifat hewan peliharaan yang tidak terlalu manja. Temuan ini sejalan dengan pendapat Harsiati (2014:20) bahwa Deskripsi bagian berisi perincian bagian objek tetapi diperinci berdasarkan tanggapan subjektif penulis. Perincian dapat berisi apa yang dilihat, didengar, dan dirasakan penulis.

Berdasarkan hasil analisis data, ditemukan bahwa bagian simpulan pada teks deskripsi siswa berisi berisi kesan mengenai objek yang sudah digambarkan. Berikut ini dapat dilihat beberapa contoh data struktur isi bagian simpulan.

(6) Keistimewaan Pulau Bali ialah memiliki banyak villa dimana-mana contohnya di Kota Ubud, disana banyak villa yang indah, bersih, dan rapi. Seakan villa-villa tersebut berbaris rapi menunggu kita. Pada pagi hari kita bisa menikmati hembusan angin yang sejuk dan segar. Sangat kaya keindahan pantai di Indonesia, kita bangga menjadi anak Indonesia karena memiliki banyak berjuta-juta pulau dan pantai. (03/SI-S)

(7) Guruku tidak sekedar memberikan tugas kepada muridnya, tetapi guruku mengajarkan terlebih dahulu cara mengerjakannya. Dia sangat baik seperti malaikat. (27/ SI-S)

Hasil penelitian menunjukkan bahwa pada data (03/SI-S) siswa menuliskan simpulan berisi kesan terhadap objek yang dideskripsikan. Pada data tersebut siswa menuliskan kesan berupa keistimewaan Pulau Bali, keindahan pantai Indonesia, dan juga kesan bangga menjadi anak Indonesia dengan banyaknya pulau dan pantai di Indonesia. Pada data (27/SI-S) siswa menuliskan simpulan berisi kesan terhadap objek yang dideskripsikan. Pada data tersebut siswa menuliskan kesan berupa rasa senang dan bangga memiliki guru yang sangat baik seperti malaikat. Temuan penelitian ini sejalan dengan pendapat Harsiati (2014:20) bahwa simpulan berisi kesan umum dari penulis terhadap objek.

Berdasarkan hasil analisis data, ditemukankarangan teks deskripsi siswa dengan tatanan unsur yang lengkap. Unsur tersebut berupa identifikasi, deskripsi bagian, dan simpulan. Identifikasi pada teks deskripsi berisi mengenai objek yang dideskripsikan. Berikut ini dapat dilihat beberapa contoh data dengan tatanan unsur yang lengkap.

(8) Indonesia sangat terkenal dengan pulaunya yang sangat banyak, dari yang berpenghuni sampai tidak berpenghuni. Indonesia juga memiliki pulau yang eksotis, contohnya Pulau Bali. Pulau Bali letaknya disebelah Timur Pulau Jawa, disebelah Barat kepulauan Nusa Tenggara Barat dan Pulau Bali jika dilihat secara astronomi terletak di $8,3^{\circ}$ LS $-8,5^{\circ}$ LS dan $18,25^{\circ}$ BT $-116^{\circ}$ BT.

Pantai Bali sering dikunjungi oleh wisatawan Manca Negara karena keindahannya yang sangat memukau dari pantai sampai perbukitannya, salah satunya Pantai Kuta, Pantai Pandawa, Pantai Sanur, Pantai Tanah Lot, dll. Gempuran ombak dari berbagai pantai dinikmati oleh wisatawan seakan ombak ingin menghampiri wisatawan.Perbukitannya yang indah sering digunakan untuk paralayang salah satunya di Pantai Pandawa. Keindahan Pulau Bali pada petang hari sangat indah, kita bisa melihat matahari yang akan tenggelam berwarna kuning keemasan yang seakan kita tersihir oleh matahari yang akan tenggelam.

Keistimewaan Pulau Bali ialah memiliki banyak villa dimana-mana contohnya di Kota Ubud, disana banyak villa yang indah, bersih, dan rapi.Seakan villa-villa tersebut berbaris rapi menunggu kita. Pada pagi hari kita bisa menikmati hembusan angin yang sejuk dan segar. Sangat kaya keindahan kaya keindahan pantai di Indonesia, kita bangga menjadi anak Indonesia karena memiliki banyak berjuta-juta pulau dan pantai. (03/SI-I/SI-DB/SI-S)

(9) Guruku adalah seorang guru yang sangat cantik, kulitnya berwarna kuning langsat. Dia memakai hijab yang membuat wajahnya selalu bercahaya. Dia selalu mengajar muridnya dengan penuh kasih sayang. Guruku bernama Sri Astiningsih S. Pd. Dia mempunyai mata yang sedikit sipit, tetapi dia tetap terlihat cantik.

Guruku adalah orang yang sabar, dia tidak pernah mengeluh saat mengajar muridnya. Seringkali terdengar guruku sedang marah karena muridnya tidak bisa diam. Selain kesabaran yang dia miliki ia juga tekun sekali beribadah, dia tidak pernah meninggalkan sholat. Dia juga sangat ramah sekali.

Guruku tidak sekedar memberikan tugas kepada muridnya, tetapi guruku mengajarkan terlebih dahulu cara mengerjakannya. Dia sangat baik seperti malaikat. (27/SI-I/SI-DB/SI-S)

Hasil penelitian menunjukkan bahwa karangan teks deskripsi siswa ditemukan tatanan unsur yang lengkap berupa bagian identifikasi, bagian deskripsi bagian, dan bagian simpulan. Pada data (03/SI-I/SI-DB/SI-S) siswa menuliskan identifikasi yang dijelaskan pada paragraf pertama yang di dalamnya mendeskripsikan objek secara singkat. Bagian identifikasi tersebut menjelaskan nama objek, lokasi, dan pernyataan umum tentang objek. Pada paragraf kedua siswa menuliskan deskripsi bagian yang menjelaskan perincian yang dapat dilihat dan dirasakan. Pada paragraf ketiga siswa menuliskan simpulan yang di dalamnya menyatakan kesan penulis terhadap objek. Pada data (27/SI-I/SI-DB/SI-S) siswa menuliskan identifikasi yang dijelaskan pada paragraf pertama yang didalamnya mendeskripsikan objek secara singkat. Bagian identifikasi tersebut menjelaskan nama objek, dan pernyataan umum terkait objek yang dideskripsikan.Pada paragraf kedua berisi deskripsi bagian yang menjelaskan perincian objek yang dapat dilihat, didengar, dan dirasakan. Pada paragraf ketiga berisi simpulan yang di dalamnya menyatakan kesan 
penulis terhadap objek. Temuan penelitian ini senada dengan pendapat Harsiati (2014:20) bahwa struktur teks tanggapan deskripsi mencakup identifikasi, deskripsi bagian, dan simpulan. Identifikasi atau gambaran umum berisi nama objek yang dideskripsikan, lokasi, sejarah lahirnya, makna nama, pernyataan umum tentang objek. Deskripsi bagian berisi perincian bagian objek tetapi diperinci berdasarkan tanggapan subjektif penulis. Perincian dapat berisi apa yang dilihat, didengar, dan dirasakan penulis. Simpulan berisi kesan umum dari penulis terhadap objek.

Berdasarkan hasil analisis data, ditemukankarangan teks deskripsi siswa dengan tatanan unsur yang tidak lengkap. Pada bagian identifikasi tidak dijelaskan secara lengkap gambaran umum mengenai objek yang dideskripsikan. Begitu pula ditemukan teks deskripsi tanpa disertai simpulan. Berikut ini dapat dilihat beberapa contoh data dengan tatanan unsur yang tidak lengkap.

(10) Ikan aligatorku bernama Bagas. Dia memiliki ciri fisik berupa deretan gigi yang sangat tajam. Dia adalah hewan karnivora, yaitu hewan pemakan daging.

Si Bagas itu suka pemarah. Dia suka memangsa hewan lain. Dia lebih suka menyendiri daripada berkelompok.Si Bagas adalah ikan pendiam. Berenangnya cepat seperti motor balap.

Dia memiliki sisik bercorak polos.Dia bisa melompat sejauh 1 meteran.Dia memiliki tubuh torpedo. (09/SI-I/SI-DB)

(11) Kakak sepupuku bernama Isna. Kakak sepupuku lahir di Trenggalek, 12 Juli 1996. Dia berumur 20 tahun. Warna kulitnya sawo matang. Dia berambut panjang dan lurus.

Kakak sepupuku biasanya berolahraga dan lari pagi. Dia sering sekali marah, karena kesalahan sedikit saja dia akan marah. Dia kalau mau mandi sangatlah susah. Susah disuruh mandi dan dikamar mandi dia sangat lama.

Kakak sepupuku suka dengan boneka. Jika dia ada boneka dikamarnya, dia akan tertidur dengan bonekannya itu. Makanan kesukaannya adalah mie goring.Minuman kesukaannya adalah jus jambu. (19/SI-I/SI-DB)

Hasil penelitian menunjukkan bahwa karangan teks deskripsi siswa ditemukan tatanan unsur yang tidak lengkap. Pada bagian identifikasi tidak ditemukan adanya pernyataan umum tentang objek. Pada data (09/SI-I/SIDB/SI-S) siswa menuliskan identifikasi yang dijelaskan pada paragraf pertama yang di dalamnya mendeskripsikan objek secara singkat, namun tidak ada pernyataan umum tentang objek yang dideskripsikan. Pada bagian identifikasi tersebut hanya menjelaskan nama objek, tidak ada kalimat berupa pernyataan umum tentang objek. Pada paragraf kedua siswa menuliskan deskripsi bagian yang menjelaskan perincian yang dapat dilihat. Pada paragraf ketiga siswa tidak menuliskan simpulan berupa kesan melainkan deskripsi bagian yang menjelaskan perincian yang dapat dilihat dan didengar. Pada data (19/SI-I/SI-DB) strukturnya tanpa disertai simpulan, siswa hanya menuliskanidentifikasi dan deskripsi bagian. Pada paragraf pertama berisi identifikasi yang di dalamnya mendeskripsikan objek secara singkat. Bagian identifikasi tersebut menjelaskan nama objek dan pernyataan umum terkait objek yang dideskripsikan. Pada paragraf kedua berisi deskripsi bagian yang menjelaskan perincian yang dapat dilihat dan dirasakan. Pada paragraf ketiga tidak berisi simpulan berupa kesan melainkan deskripsi bagian yang menjelaskan perincian yang dapat dilihat. Temuan penelitian ini tidak sesuai dengan pendapat Harsiati (2014:20) bahwa struktur teks tanggapan deskripsi mencakup identifikasi, deskripsi bagian, dan simpulan. Identifikasi atau gambaran umum berisi nama objek yang dideskripsikan, lokasi, sejarah lahirnya, makna nama, pernyataan umum tentang objek. Deskripsi bagian berisi perincian bagian objek tetapi diperinci berdasarkan tanggapan subjektif penulis. Perincian dapat berisi apa yang dilihat, didengar, dan dirasakan penulis.Simpulan berisi kesan umum dari penulis terhadap objek.

\section{Ciri Kebahasaan Teks Deskripsi}

Berdasarkan hasil analisis data, ditemukan ciri kebahasaan teks deskripsi siswa kelas VII SMP Negeri 11 Malang berupa kata kerja aksikata kerja aksi, kata sifat untuk mendeskripsikan objek, kata benda terkait objek yang dideskripsikan, kata-kata yang dapat memancing kesan serta citra indrawi dan suasana batiniah pembaca yang lebih dominan pada citraan visual dan citraan gerak, sinonim, kata khusus, kalimat rincian, dan kalimat rincian untuk mengongkretkan. Berikut paparan dan pembahasannya.

Berdasarkan hasil analisis data, ditemukan karangan teks deskripsi siswa dengan ciri kebahasaan berupa kata kerja aksi. Kata kerja aksi pada teks deskripsi digunakan untuk mendeskripsikan perilaku atau kondisi objek. Kata kerja aksi berdasarkan bentuknya terbagi menjadi asal dan turunan. Berikut ini dapat dilihat beberapa contoh data ciri kebahasaan berupa kata kerja aksi.

(12) Melihat, menikmati, dan berbaris (03/CK-KKA)

(13) Merawat dan bersepeda (04/CK-KKA)

Hasil penelitian menunjukkan bahwa ditemukan karangan teks deskripsi siswa dengan ciri kebahasaan berupa kata kerja aksi. Karangan teks deskripsi siswa secara keseluruhan memiliki ciri kebahasaan berupa kata kerja aksi. Pada data (03/CK-KKA) menunjukkan bahwa kata-kata yang digunakan siswa merupakan kata kerja aksi. Kata kerja aksi tersebut mendeskripsikan kondisi suatu objek, yaitu Pulau Bali. Kata kerja aksi tersebut termasuk ke dalam verba turunan, karena terdapat imbuhan me- dan akiran -i. Pada data (04/CK-KKA) menunjukkan bahwa kata-kata yang digunakan siswa merupakan kata kerja aksi. Kata kerja aksi yang digunakan siswa sesuai dengan perilaku objek yang sedang dideskripsikan, yaitu kakek. Kata kerja aksi tersebut termasuk ke dalam verba turunan, karena terdapat imbuhan me- dan ber-. Temuan penelitian ini sejalan dengan pendapat Priyatni (2014:73) bahwa teks deskripsi memiliki ciri bahasa yang menggunakan kata kerja aksi untuk mendeskripsikan perilaku atau kondisi objek. Temuan penelitian ini juga sesuai dengan pendapat Muslich (2010: 38) bahwa ada dua macam dasar yang dipakai sebagai dasar 
pembentukan verba: (1) dasar yang tanpa afiks (dasar bebas) yang berdiri sendiri, misalnya darat, pergi, marah; dan (2) dasar yang bisa ditentukan jika sudah berafiks (dasar terikat); dasar demikian bersifat prakategori, misalnya temu, juang, dan selenggara. Kata-kata terakhir ini bisa disebut verba jika sudah ditambah afiks, sehingga menjadi bertemu, berjuang, menyelenggarakan. Proses penurunan verba dalam bahasa Indonesia terdapat prefiks verbal meng-, per-, dan ber-. Di samping itu, terdapat prefiks di- dan ter- yang pada jenis klausa atau kalimat tertentu menggantikan meng-. Jumlah sufiks hanya dua, yaitu -kan dan $-i$, sedangkan verba asal dapat berdiri sendiri. Oleh karena itu, tanpa afiks tentu saja, ia sudah dapat berdiri dalam kalimat, klausa, formal, ataupun informal.

Berdasarkan hasil analisis data, ditemukan karangan teks deskripsi siswa dengan ciri kebahasaan berupa kata sifat untuk mendeskripsikan objek. Kata sifat untuk mendeskripsikan objek dalam teks deskripsi menyatakan suatu penjelasan yang membuatnya lebih spesifik. Kata sifat untuk mendeskripsikan objek berdasarkan bentuknya dapat dibedakan menjadi tiga, yaitu ajektiva dasar, ajektiva turunan, dan ajektiva majemuk. Berikut ini dapat dilihat beberapa contoh data ciri kebahasaan berupa kata sifat untuk mendeskripsikan objek.

(14) Tinggi, bersih, dan indah (02/CK-KS)

(15) Indah, luas, dan rindang (06/CK-KS)

Hasil penelitian menunjukkan bahwa ditemukan teks deskripsi siswa dengan ciri kebahasaan berupa kata sifat untuk mendekripsikan objek. Karangan teks deskripsi siswa secara keseluruhan memiliki ciri kebahasaan berupa kata sifat untuk mendekripsikan objek. Hal tersebut ditunjukkan pada data (02/CK-KS) yang menunjukkan bahwa kata-kata yang digunakan siswa merupakan kata sifat untuk mendeskripsikan objek. Kata sifat tersebut melengkapi objek yang sedang dideskripsikan, yaitu keadaan Pantai Pandawa. Kata sifat untuk mendeskripsikan objek tersebut termasuk ke dalam ajektiva dasar, karena dapat diuji dengan kata sangat atau lebih. Pada data (06/CK-KS) menunjukkan bahwa kata-kata yang digunakan siswa merupakan kata sifat untuk mendeskrisikan objek. Kata sifat untuk mendeskripsikan objek yang digunakan siswa sesuai dengan objek yang sedang dideskripsikan, yaitu rumah. Kata sifat untuk mendeskripsikan objek tersebut termasuk ke dalam ajektiva dasar, karena dapat diuji dengan kata sangat atau lebih. Temuan penelitian ini sejalan dengan pendapat Priyatni (2017:73) bahwa teks deskripsi memiliki ciri bahasa yang menggunakan kata sifat untuk mendeskripsikan objek. Temuan penelitian ini juga sesuai dengan pendapat Kridalaksana (2005:59) bahwa ajektiva dasar dapat diuji dengan kata sangat, lebih, misalnya adil, bagus, cekatan, diam, elok, fatal, dan gaduh.

Berdasarkan hasil analisis data, ditemukan karangan teks deskripsi siswa dengan ciri kebahasaan berupa kata benda terkait objek yang dideskripsikan. Kata benda terkait objek yang dideskripsikan dalam teks deskripsi menyatakan nama atau segala yang dibendakan. Kata benda terkait objek yang dideskripsikan berdasarkan bentuknya dibagi menjadi nomina dasar, nomina turunan, nomina yang bereduplikasi, dan nomina majemuk. Berikut ini dapat dilihat beberapa contoh data ciri kebahasaan berupa kata benda terkait objek yang dideskripsikan.

(16) Irsyad dan landak (10/CK-KB)

(17) Bagera dan cicak (17/CK-KB)

Hasil penelitian ini menunjukkan bahwa ditemukan teks deskripsi siswa dengan ciri kebahasaan berupa kata benda terkait objek yang dideskripsikan. Karangan teks deskripsi siswa secara keseluruhan memiliki ciri kebahasaan berupa kata benda terkait objek yang dideskripsikan. Hal tersebut ditunjukkan Pada data (10/CK-KB) menunjukkan bahwa kata-kata yang digunakan siswa merupakan kata benda terkait objek yang dideskripsikan. Kata-kata tersebut menyatakan nama atau segala yang dibendakan berkaitan dengan objek yang dideskripsikan, yaitu Irsyad. Irsyad termasuk ke dalam nomina dasar (khusus) yang mengacu kepada diri orang. Landak termasuk ke dalam nomina dasar (khusus). Pada data (17/CK-KB) menunjukkan bahwa kata-kata yang digunakan siswa merupakan kata benda terkait objek yang dideskripsikan. Kata-kata tersebut menyatakan nama atau segala yang dibendakan berkaitan dengan objek yang dideskripsikan, yaitu kucing bernama Bagera. Bagera termasuk ke dalam nomina dasar (khusus). Cicak termasuk ke dalam nomina dasar (khusus). Pada data (22/CK-KB) menunjukkan bahwa kata-kata yang digunakan siswa merupakan kata benda terkait objek yang dideskripsikan. Kata-kata tersebut menyatakan nama atau segala yang dibendakan berkaitan dengan objek yang dideskripsikan, yaitu adik bernama Ridho. Ridho termasuk ke dalam nomina dasar (khusus) yang mengacu pada diri orang. Macan termasuk ke dalam nomina dasar (khusus). Teman termasuk ke dalam nomina dasar (khusus) yang mengacu pada pemeran. Temuan penelitian ini sejalan dengan pendapat Priyatni (2014:73) bahwa teks deskripsi memiliki ciri bahasa yang menggunakan kata benda terkait dengan objek yang dideskripsikan (contoh: Pulau Nusakambangan, Pantai Karangpandan, hutan tropis). Temuan penelitian ini juga sesuai dengan pendapat Muslich (2010: 70) bahwa nomina dasar selalu berbentuk monomorfemik karena hanya terdiri atas satu morfem. Nomina ini dikelompokkan ke dalam (1) nomina umum (gambar, kesatria, malam, meja, minggu, pisau, rumah, semangat, tahun) dan (2) nomina khusus (adik, atas, Bawuk, Selasa, nutir muka, paman, ini, Tulungagung, batang).

Berdasarkan hasil analisis data, ditemukan karangan teks deskripsi siswa dengan ciri kebahasaan berupa katakata yang dapat memancing kesan serta citra indrawi dan suasana batiniah pembaca. Berikut ini dapat dilihat beberapa contoh databerupa kata-kata yang dapat memancing kesan serta citra indrawi dan suasana batiniah pembaca.

(18) Matanya bersinar seperti bulan. (08/CK-KMMP)

(19) Ozil memiliki bulu yang halus seperti sutra. (18/CK-KMMP)

Hasil penelitian ini menunjukkan bahwa ditemukan teks deskripsi siswa dengan ciri kebahasaan berupa katakata yang dapat memancing kesan serta citra indrawi dan suasana batiniah pembaca. Karangan teks deskripsi siswa secara keseluruhan memiliki ciri kebahasaan berupa kata-kata yang dapat memancing kesan serta citra indrawi dan 5 | BASINDO : Jurnal Kajian Bahasa, Sastra Indonesia, dan Pembelajarannya 
batiniah pembaca. Pada data (08/CK-KMMP) menunjukkan bahwa kata-kata yang digunakan siswa merupakan katakata yang dapat memancing kesan serta citra indrawi pembaca. Matanya bersinar seperti bulan termasuk ke dalam citraan visual, karena objek yang dideskripsikan dapat dilihat oleh mata. Rincian tersebut merupakan objek penglihatan imajinatif yang sengaja dibangkitkan oleh penulis. Pada data (18/CK-KMMP) menunjukkan bahwa katakata yang digunakan siswa merupakan kata-kata yang dapat memancing kesan serta citra indrawi pembaca. Ozil memiliki bulu yang halus seperti sutra termasuk ke dalam citraan visual, karena objek yang dideskripsikan dapat dilihat oleh mata. Rincian tersebut merupakan objek penglihatan imajinatif yang sengaja dibangkitkan oleh penulis. Temuan penelitian ini juga sesuai dengan pendapat Nurgiyantoro (2014:277) bahwa citraan terkait dengan pancaindera manusia, maka citraan juga ada lima buah. Kelima jenis indra manusia dan kelima jenis citraan itu adalah citraan penglihatan (visual), pendengaran (auditoris), gerak (kinestetik), rabaan (taktil termal), dan penciuman (olfaktori).

Berdasarkan hasil analisis data, ditemukan karangan teks deskripsi siswa dengan ciri kebahasaan berupa sinonim. Kata sinonim dalam teks deskripsi menyatakan emosi yang kuat. Berikut ini dapat dilihat beberapa contoh data ciri kebahasaan berupa sinonim.

(20) memukau (03/CK-KS)

(21) rapuh dan bersusah payah (21/CK-KS)

Hasil penelitian ini menunjukkan bahwa ditemukan teks deskripsi siswa dengan ciri kebahasaan berupa sinonim. Sebagian karangan teks deskripsi siswa memiliki ciri kebahasaan berupa sinonim. Hal tersebut ditunjukkan pada data (03/CK-KS) yang menunjukkan bahwa kata yang digunakan siswa merupakan sinonim. Kata Memukau dalam data tersebut menjelaskan keindahan yang dimiliki pulau Bali. Pada data (21/CK-KS) menunjukkan bahwa kata-kata yang digunakan siswa merupakan sinonim. Kata rapuh dalam data tersebut menjelaskan bahwa benda yang terdapat di dasar laut itu sudah rusak dan kata bersusah payah dalam data tersebut menjelaskan bahwa membutuhkan tenaga yang cukup banyak untuk dapat ke puncak candi Borobudur. Temuan penelitian ini sejalan dengan pendapat Harsiati (2014:11) yang mengemukakan bahwa ciri teks deskripsi dari segi penggunaan bahasa menggunakan kata sinonim dengan emosi kuat (indah diungkapkan dengan sinonim yang lebih memiliki emosi kuat yaitu elok, permai, molek, mengagumkan, memukau, menakjubkan).

Berdasarkan hasil analisis data, ditemukan karangan teks deskripsi siswa dengan ciri kebahasaan berupa kata khusus. Kata khusus dalam teks deskripsi menyatakan kata yang ruang lingkup dan maknanya lebih sempit. Berikut ini dapat dilihat beberapa contoh data ciri kebahasaan berupa kata khusus.

(22) polos dan ikan aligator. (09/CK-KH)

(23) pendek, besar, dan panjang (11/CK-KH)

Hasil penelitian ini menunjukkan bahwa ditemukan teks deskripsi siswa dengan ciri kebahasaan berupa kata khusus. Karangan teks deskripsi siswa secara keseluruhan memiliki ciri kebahasaan berupa kata khusus. Pada data (09/CK-KH) menunjukkan bahwa kata-kata yang digunakan siswa merupakan kata khusus. Kata polos dan ikan aligator termasuk ke dalam kata khusus untuk mengongkretkan corak dari objek yang dideskripsikan, yaitu berupa ikan. Kata khusus berupa aligator untuk mengongkretkan objek berupa ikan. Pada data (11/CK-KH) menunjukkan bahwa katakata yang digunakan siswa merupakan kata khusus.Kata pendek, besar, dan panjang termasuk ke dalam kata khusus untuk mengongkretkan bulu mata yang panjang dan badan yang pendek dan besar dari objek yang dideskripsikan. Temuan penelitian ini sejalan dengan pendapat Harsiati (2014:11) yang mengemukakan bahwa ciri teks deskripsi dari segi penggunaan bahasa menggunakan kata-kata khusus untuk mengongkretkan (warna dirinci merah, kuning, hijau).

Berdasarkan hasil analisis data, ditemukan karangan teks deskripsi siswa dengan ciri kebahasaan berupa kalimat rincian. Kalimat rincian dalam teks deskripsi merupakan kalimat yang berisi uraian atau rincian-rincian detail dari kalimat utama. Berikut ini dapat dilihat beberapa contoh data ciri kebahasaan berupa kalimat rincian.

(24) Fasilitas umum seperti mushola, tempat membeli makanan, serta kamar mandi. (05/CK-KR)

(25) Ibuku pernah mengalami kecelakaan saat memasak, seperti terkena pisau, menjatuhkan alat masak. (14/CK-KR)

Hasil penelitian ini menunjukkan bahwa ditemukan teks deskripsi siswa dengan ciri kebahasaan berupa kalimat rincian. Sebagian dari karangan teks deskripsi siswa terdapat ciri kebahasaan berupa kalimat rincian. Hal tersebut ditunjukkan pada data (05/CK-KR) yang menunjukkan bahwa karangan teks deskripsi siswa menggunakan kalimat rincian. Kalimat fasilitas umum seperti mushola, tempat membeli makanan, serta kamar mandi merupakan kalimat rincian yang menjelaskan secara detail apa saja fasilitas umum yang disediakan. Pada data (14/CK-KR) menunjukkan bahwa karangan teks deskripsi siswa menggunakan kalimat rincian. Kalimat ibuku pernah mengalami kecelakaan saat memasak, seperti terkena pisau, menjatuhkan alat masak merupakan kalimat rincian yang menjelaskan secara detail kecelakan apa saja yang pernah dialami oleh ibu. Temuan penelitian ini sejalan dengan pendapat Harsiati (2014:11) mengemukakan bahwa ciri teks deskripsi dari segi penggunaan bahasa menggunakan kalimat rincian (terumbu karang berwarna-warni. Ada terumbu karang orange, abu-abu, hijau muda), menggunakan bahasa sehingga pembaca seolah-olah melihat, mendengar, dan merasakan apa yang dideskripsikan, dan teks deskripsi yang memunculkan kata ganti orang.

Berdasarkan hasil analisis data, ditemukan karangan teks deskripsi siswa dengan ciri kebahasaan berupa kalimat rincian untuk mengongkretkan. Kalimat rincian untuk mengongkretkan dalam teks deskripsi berisi penjelasan terperinci untuk menjelaskan kalimat lain yang lebih umum. Berikut ini dapat dilihat beberapa contoh data ciri kebahasaan berupa kalimat untuk mengongkretkan.

(26) kakekku memiliki sifat yang sabar. Dia tidak pernah marah dihadapan cucu-cucunya. (04/CK-KRM)

6 | BASINDO : Jurnal Kajian Bahasa, Sastra Indonesia, dan Pembelajarannya 
Hasil penelitian ini menunjukkan bahwa ditemukan teks deskripsi siswa dengan ciri kebahasaan berupa kalimat rincian untuk mengongkretkan. Sebagian karangan teks deskripsi siswa memiliki ciri kebahasaan berupa kalimat rincian untuk mengongkretkan. Hal tersebut ditunjukkan pada data (04/CK-KRM) yang menunjukkan bahwa siswa menggunakan kalimat rincian untuk mengongkretkan. Kalimat kakekku memiliki sifat yang sabar. Dia tidak pernah marah dihadapan cucu-cucunya merupakan kalimat rincian untuk mengongkretkan. Kalimat Dia tidak pernah marah dihadapan cucu-cucunya merupakan kalimat terperinci yang menjelaskan kalimat sebelumnya yang lebih umum, yaitu kakekku memiliki sifat yang sabar. Pada data (19/CK-KRM) menunjukkan bahwa kata-kata yang digunakan siswa merupakan kalimat rincian untuk mengongkretkan. Kalimat dia sering sekali marah. Karena kesalahan sedikit saja dia akan marah merupakan kalimat rincian untuk mengongkretkan. Kalimat karena kesalahan sedikit saja dia akan marah merupakan kalimat terperinci yang menjelaskan kalimat sebelumnya yang lebih umum, yaitu dia sering sekali marah. Temuan penelitian ini sejalan dengan pendapat Harsiati (2014:11) yang mengemukakan bahwa ciri teks deskripsi dari segi penggunaan bahasa menggunakan kalimat rincian untuk mengongkretkan (ibuku orang yang sangat baik. Dia berusaha menolong semua orang. Dia ramah dan tutur katanya lembut kepada siapa saja).

\section{PENUTUP \\ Simpulan}

Pertama, dari penelitian yangtelah dilakukan dapat disimpulkan bahwa hasil analisis teks deskripsi dilihat dari struktur isi karya siswa kelas VII SMP Negeri 11 Malang memiliki struktur isi berupa identifikasi yang didalamnya berisi gambaran umum terkait objek yang dideskripsikan berupa nama objek, lokasi, makna nama, sejarah lahirnya, dan pernyataan umum tentang objek. Pada bagian deskripsi bagian didalamnya berisi rincian mengenai objek seperti apa yang dapat dilihat, didengar, dan dirasakan oleh penulis. Pada bagian simpulan didalamnya berisi kesan terhadap objek. Penelitian ini juga memiliki tatanan unsur teks deskripsi yang lengkap. Seluruh siswa menuliskan identifikasi pada bagian pembuka yang menjelaskan tentang gambaran singkat mengenai objek yang dideskripsikan.Seluruh siswa juga menuliskan deskripsi bagian pada bagian isi yang menjelaskan tentang rincian mengenai objek yang dideskripsikan. Seluruh siswa juga menuliskan simpulan pada bagian penutup yang menjelaskan kesan terhadap objek yang dideskripsikan. Namun ditemukan juga teks deskripsi dengan tatanan unsur yang tidak lengkap. Data tersebut tidak berisi identifikasi yang lengkap dan tidak memiliki simpulan berupa kesan terhadap objek melainkan berisi deskripsi bagian yang menjelaskan rincian mengenai objek.

Kedua, dari penelitian yangtelah dilakukan dapat disimpulkan bahwa hasil analisis teks deskripsi dilihat dari ciri kebahasaan karya siswa kelas VII SMP Negeri 11 Malang memiliki ciri kebahasaan berupa kata kerja aksi dari verba asal dan verba turunan, kata sifat untuk mendeskripsikan objekyang lebih dominan pada ajektiva dasar, kata benda terkait objek yang dideskripsikan yang lebih dominan pada nomina dasar (umum) dan nomina dasar (khusus), katakata yang dapat memancing kesan serta citra indrawi dan suasana batiniah pembaca yang lebih dominan pada citraan visual dan citraan gerak, sinonim, kata khusus, kalimat rincian, dan kalimat rincian untuk mengongkretkan.

Saran

Berdasarkan kesimpulan maka dikemukakan saran yang ditujukan kepada guru bahasa Indonesia dan peneliti lain. Pertama, saran untuk guru bahasa Indonesia agar lebih memperhatikan dan mengevaluasi struktur isi dalam teks deskripsi karya siswa dengan cara lebih memantapkan materi terutama mengenai struktur isi bagian simpulan dan ciri kebahasaan mengenai kata-kata yang dapat memancing kesan pembaca. Kedua, saran bagi peneliti lain yang ingin melakukan penelitian dengan topik yang sama atau mengembangkannya, sebaiknya banyak mencari referensi buku yang berkaitan dengan teks deskripsi agar dapat menambah pengetahuan bagi pembaca.

\section{DAFTAR RUJUKAN}

Dawud. 2008. Perspektif Pembelajaran Bahasa Indonesia. Malang: Universitas Negeri Malang (UM PRESS). Harsiati, Titik. 2014. Bahasa Indonesia Kelas VII SMP/MTs. Jakarta: Kementrian Pendidikan dan Kebudayaan. Kridalaksana, H. 2005. Kelas Kata dalam Bahasa Indonesia. Jakarta: Gramedia Pustaka Utama.

Muslich, M. 2010. Garis-Garis Besar Tatabahasa Baku Bahasa Indonesia. Bandung: PT Refika Aditama.

Nurgiyantoro, B. 2014. Stilistika. Yogyakarta: GADJAH MADA UNIVERSITY PRESS.

Priyatni, E.T. 2014. Desain Pembelajaran Bahasa Indonesia dalam Kurikulum 2013. Jakarta: Bumi Aksara. 